Д-р техн. наук С.С. Альошинський, асист. О.С. Пестременко-Скрипка

Doct. of techn. sciences E. S. Alyoshinsky, assistent O.S. Pestremenko-Skripka

\title{
АНАЛІЗ ВПЛИВУ ПРОСТОЮ МІЖНАРОДНОГО ВАГОНОПОТОКУ НА ОБОРОТ ВАГОНІВ
}

\section{ANALYSIS THE INFLUENCE OF OUTAGE INTERNATIONAL CAR TRAFFIC VOLUME ON THE CARRIAGES TURN}

Вступ. Прикордонна передавальна станція здійснює повний перелік операцій у взаємодії 3 митною, прикордонною та іншими державними контролюючими службами. Згідно з наказом Укрзалізниці від 29.10.1997 р. №265/Ц станція передачі має бути організована на базі найближчої до кордону сортувальної або дільничної станції [1]. До основних операцій 3 технічного та комерційного огляду додатково додався прикордонний, митний, екологічний, ветеринарний, фітосанітарний i санітарно-епідеміологічний контроль, також значно збільшилася кількість операцій, що пов'язані 3 обробкою документів прикордонТЕКом, конторою передач i митним контролем. Всі ці операції призвели до значного збільшення простою транзитних вагонів на прикордонних передавальних станціях i, як результат, - затримки в терміні доставки експортно-імпортних вантажів до країн СНД.

Постановка проблеми. Простій затриманих вагонів на прикордонних передавальних станціях призводить до нераціонального невиробничого використання колійного розвитку станції, додаткового використання локомотивного i вагонного парку, сортувальних пристроїв, скорочення пропускної спроможності напрямів, що зв'язують сусідні держави або 
декілька країн СНД, збільшення часу обороту вагонів [2]. Для вирішення цих проблем необхідно провести аналіз причин затримок вагонів на прикордонних передавальних станціях і раціоналізацію наявних технологій пропускання експортно-імпортних вантажів через прикордонні передавальні станції.

Аналіз причин затримок вагонів. За даними Південної залізниці проведено аналіз простою затриманих вагонів на прикордонних передавальних станціях за 2010-2012 pp.

За 2010 р. на прикордонних переходах залізниці було затримано з різних причин
4325 вагонів, середньодобовий простій дорівнює 1,15 доби.

За 12 місяців 2011 р. на прикордонних передавальних станціях було затримано 16504 вагони, середньодобовий простій склав 1,03 доби.

За 2012 р. на прикордонних переходах затримано 9797 вагонів з різних причин i середньодобовий простій склав 1,34 доби.

На рис. 1 наведено кількість затриманих вагонів на прикордонних передавальних станціях Південної залізниці у експортному, імпортному та транзитному сполученні.

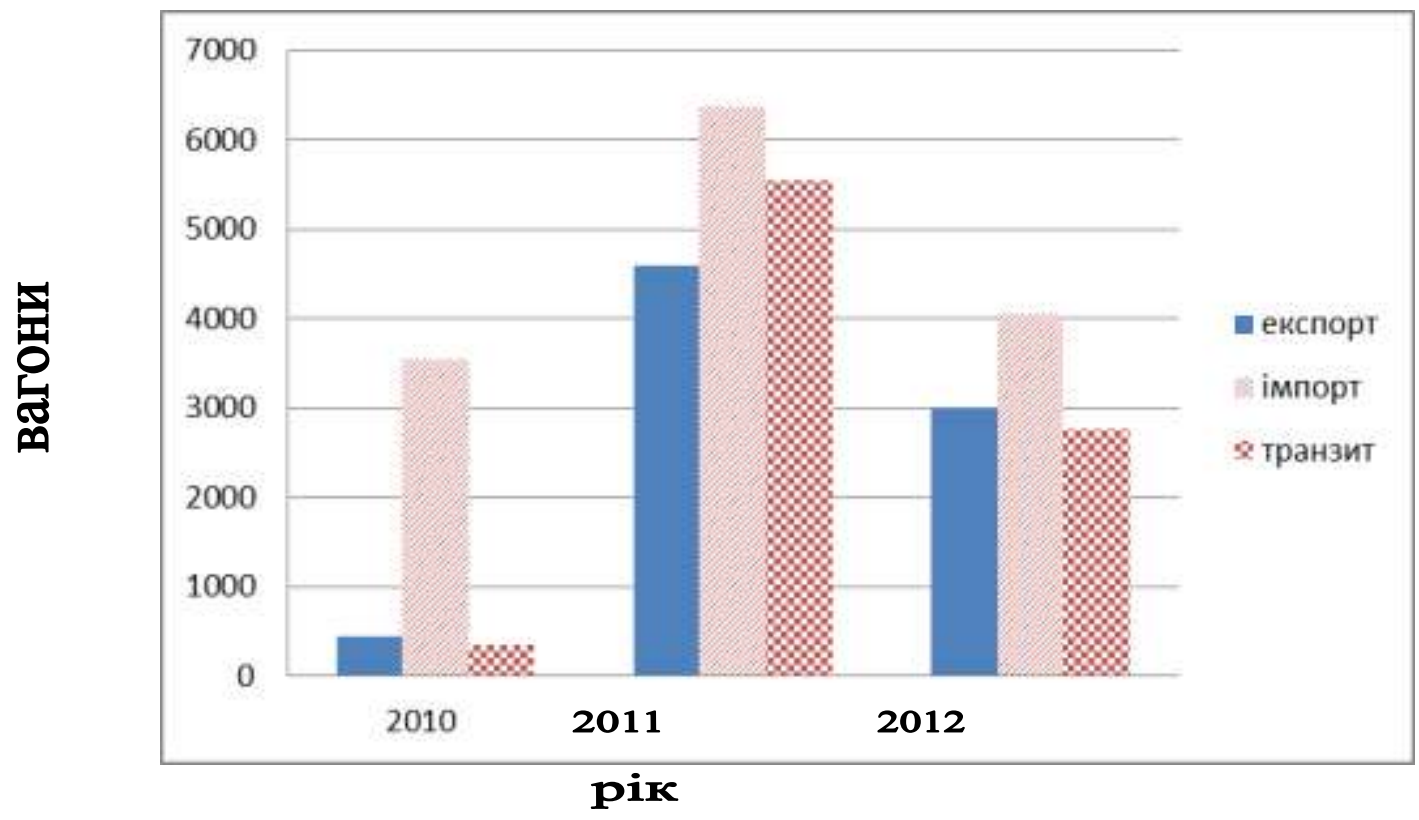

Рис. 1. Кількість затриманих вагонів на прикордонних передавальних станціях Південної залізниці за 2010-2012 pp.

Основні причини затримок вагонів на прикордонних передавальних станціях Південної залізниці за 2010-2012 pp. наведено у таблиці.

Значну частину за період з 2010 по 2012 pp. (47,8 \%) загальної кількості затриманих вагонів складають вагони, що були затримані службою вагонного господарства, 24,3 \% - вагони, що були затримані службою комерційного господарства (перевантаження, порушення упакування вантажу та ін.), 13,3\% - вагони, затримані митною службою.

Ці затримки суттєво впливають на збільшення обороту вагона, що разом із дефіцитом якісного вагонного парку створює суттєві проблеми як для Укрзалізниці, так й для вантажовласників. 
Таблиця

\begin{tabular}{|c|c|c|c|c|c|c|c|c|}
\hline $\begin{array}{c}\text { Служба / причина } \\
\text { затримки }\end{array}$ & 2010 & 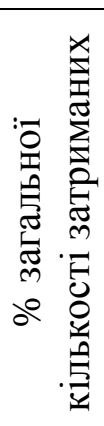 & 2011 & 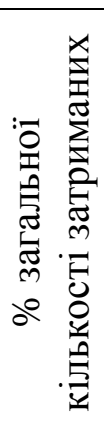 & 2012 & 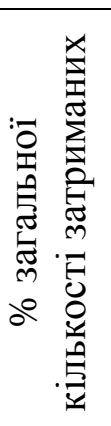 & $\begin{array}{c}\sum \\
2010-2012 \\
\text { pp. }\end{array}$ & 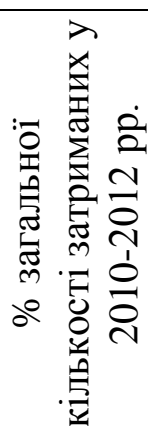 \\
\hline 1 & 2 & 3 & 4 & 5 & 6 & 7 & 8 & 9 \\
\hline $\begin{array}{l}\text { Служба вагонного } \\
\text { господарства }\end{array}$ & 2962 & 68,5 & 7005 & 42,5 & 4670 & 47,7 & 14637 & 47,8 \\
\hline $\begin{array}{l}\text { Служба } \\
\text { комерційного } \\
\text { господарства }\end{array}$ & 277 & 6,4 & 5058 & 30,6 & 2095 & 21,4 & 7430 & 24,3 \\
\hline Митна служба & 290 & 6,7 & 2601 & 15,7 & 1173 & 12 & 4064 & 13,3 \\
\hline $\begin{array}{l}\text { Транспортно- } \\
\text { експедиційні } \\
\text { причини (непра- } \\
\text { вильно оформлені } \\
\text { або відсутні пере- } \\
\text { візні документи) }\end{array}$ & 534 & 12,3 & 834 & 5,06 & 790 & 8 & 2158 & 7,05 \\
\hline Служба перевезень & 203 & 4,7 & 543 & 3,3 & 1043 & 10,64 & 1789 & 5,8 \\
\hline $\begin{array}{l}\text { Ветеринарна } \\
\text { служба }\end{array}$ & 0 & 0 & 344 & 2 & 1 & 0,01 & 345 & 1,1 \\
\hline $\begin{array}{l}\text { Карантинна } \\
\text { служба }\end{array}$ & 14 & 0,3 & 43 & 0,3 & 4 & 0,04 & 61 & 0,2 \\
\hline $\begin{array}{l}\text { Прикордонна } \\
\text { служба }\end{array}$ & 7 & 0,2 & 8 & 0,05 & 20 & 0,2 & 35 & 0,1 \\
\hline Екологічна служба & 0 & 0 & 9 & 0,05 & 0 & 0 & 9 & 0,03 \\
\hline $\begin{array}{l}\text { Санітарно- } \\
\text { епідеміологічна } \\
\text { служба }\end{array}$ & 0 & 0 & 1 & 0,01 & 0 & 0 & 1 & 0 \\
\hline $\begin{array}{l}\text { Інші причини, які } \\
\text { не залежать від } \\
\text { служб }\end{array}$ & 38 & 0,9 & 58 & 0,35 & 1 & 0,01 & 97 & 0,32 \\
\hline Разом & 4325 & 100 & 16504 & 100 & 9797 & 100 & 30626 & 100 \\
\hline
\end{tabular}

Для визначення ступеня взаємозв'язку між оборотом вагонів по залізниці та середньодобовим простоєм вагонів, що були затримані на прикордонних передавальних станціях, був використаний кореляційний аналіз.

Кореляційний аналіз полягає у визначенні міри зв'язку між двома випадковими величинами X та Y. У якості міри такого зв'язку використовується коефіцієнт кореляції - параметр, який характеризує міру лінійного взаємозв'язку між двома вибірками [3], що розраховується за формулою 


$$
r_{x y}=\frac{\sum\left(x_{i}-\bar{x}\right) \cdot\left(y_{i}-\bar{y}\right)}{\sqrt{\sum\left(x_{i}-\bar{x}\right)^{2} \cdot \sum\left(y_{i}-\bar{y}\right)^{2}}},
$$

де $x_{i}-$ значення, що приймаються у вибірці $\mathrm{X}$ (оборот вагонів по залізниці);

$y_{i}$ - значення, що приймаються у вибірці Y (простій затриманих вагонів на прикордонних передавальних станціях);

$\bar{x}$ - середня по $\mathrm{X}$ (оборот вагонів по залізниці);

$\bar{y}$ - середня по Ү (простій затриманих вагонів на прикордонних передавальних станціях).

Визначений коефіцієнт кореляції підтвердив наявність взаємозв'язку між величиною обороту та середньодобовим простоєм вагонів. У 2010 р. величина коефіцієнта кореляції склала 0,14, у 2011 р. - 0,38 та у 2012 p. - 0,17.

Кореляційний аналіз тісно пов'язаний 3 явищем регресії та регресійним аналізом. У цьому сенсі регресійний аналіз $\epsilon$ частиною теорії кореляції. Регресію слід використати для знаходження апроксимуючої кривої, яку можна провести через дану сукупність точок простою вагонів та оборотом (рис. 2-4). Якщо коефіцієнт кореляції за абсолютною величиною близький до одиниці, то для побудови залежності використовується лінійна модель [4]

$$
y=b \cdot x+a
$$

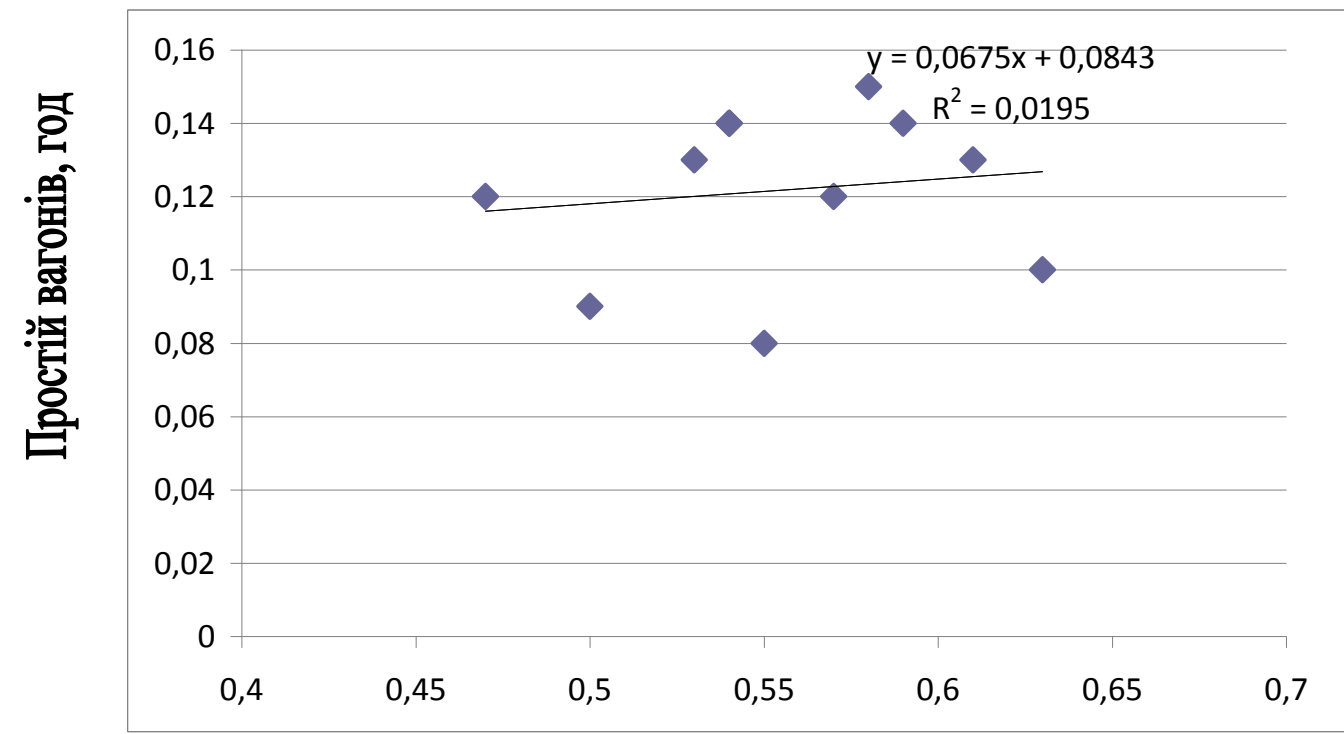

Оборот вагонів, год

Рис. 2. Залежність обороту вагонів від простою на прикордонних передавальних станціях Південної залізниці у 2010 р. 


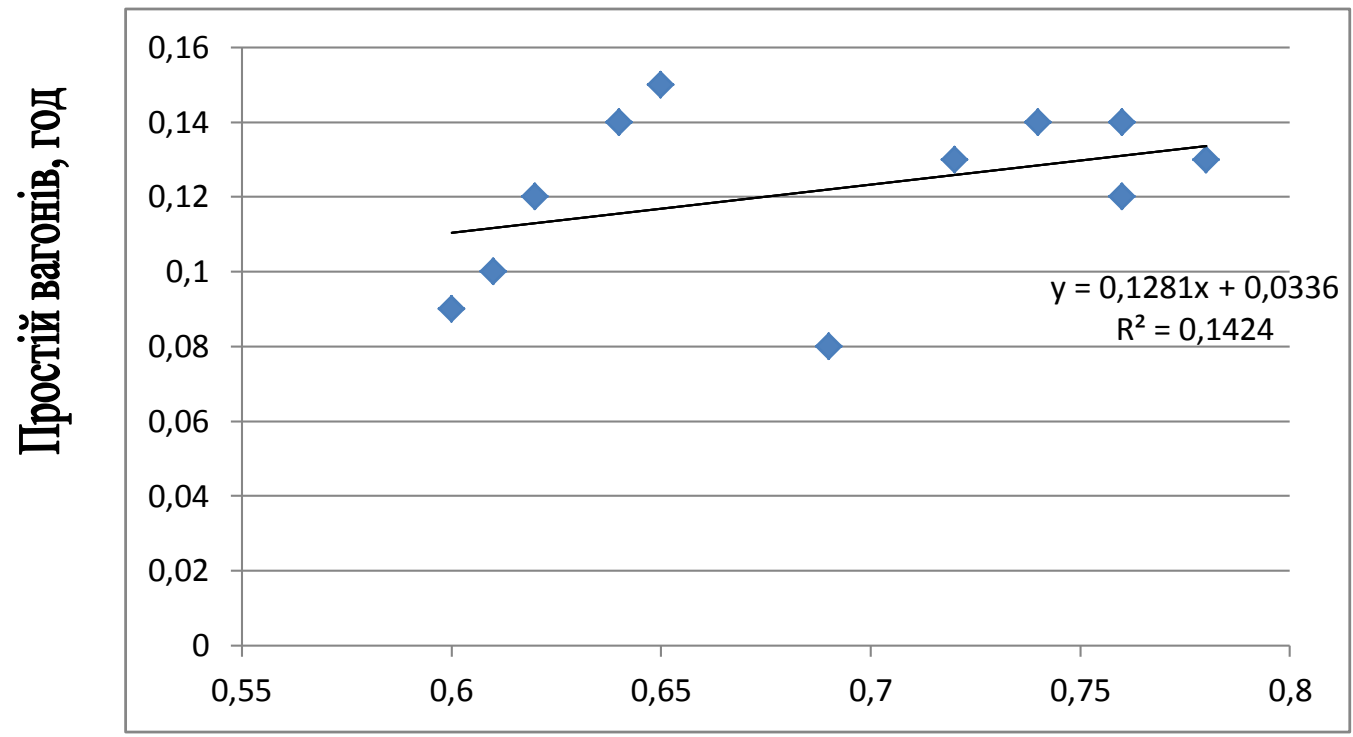

Оборот вагонів, год

Рис. 3. Залежність обороту вагонів від простою на прикордонних передавальних станціях Південної залізниці у 2011 р.

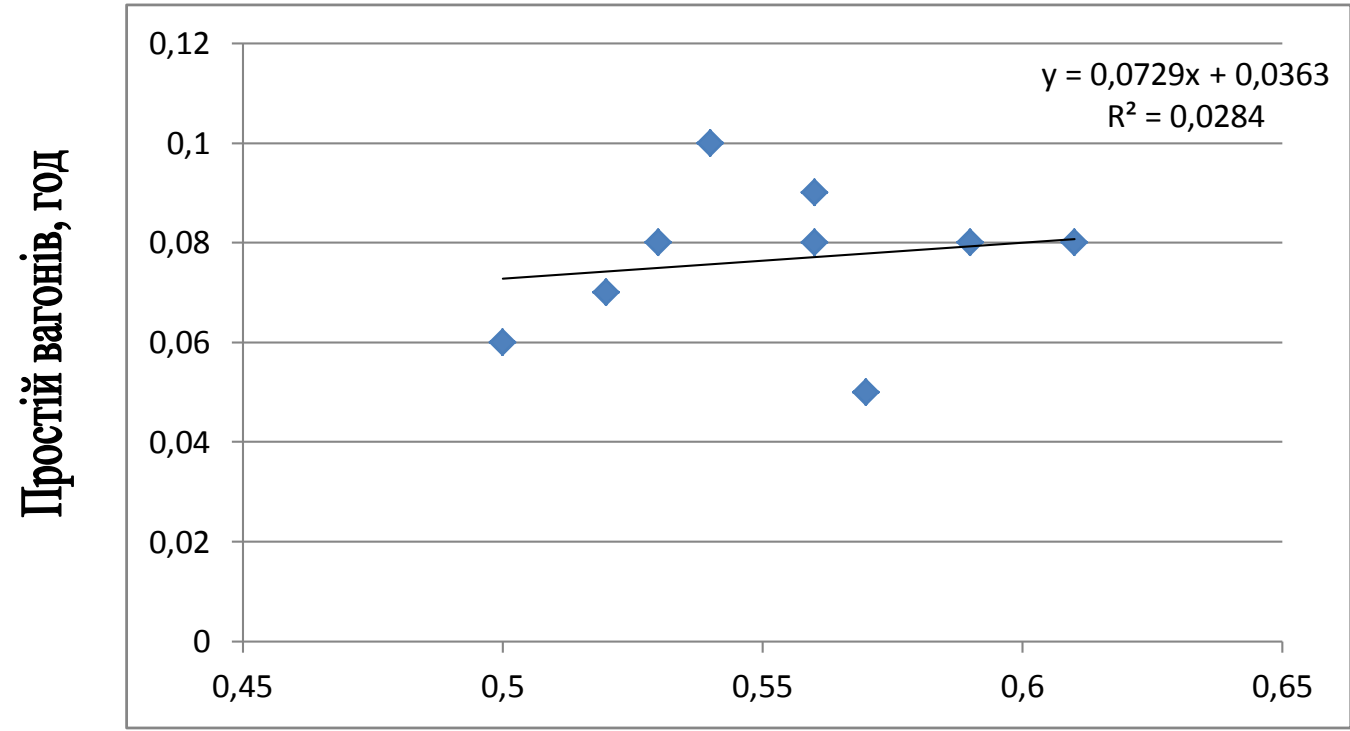

Оборот вагонів, год

Рис. 4. Залежність обороту вагонів від простою на прикордонних передавальних станціях Південної залізниці у 2012 р.

Аналіз коефіцієнтів кореляції показує, що суттєвий вплив на величину обороту вагону має простій затриманих вагонів на прикордонних передавальних станціях. При збільшенні величини простою затриманих вагонів збільшується тривалість обороту через прямо пропорційну залежність між цими величинами (рис. 2, 3, 4).

Висновок. Оборот вагонів $є$ основним якісним показником діяльності залізниць, що потребує обов'язкового виконання. За останні роки в міждержавному сполученні 
значно збільшився оборот вагонів і термін доставки експортно-імпортних вантажів. Це пов'язано зі значним простоєм затриманих вагонів на прикордонних передавальних станціях.

Дослідження показали, що існує прямо пропорційна залежність між оборотом вагонів і простоєм на прикордонних передавальних станціях.

3 метою прискорення роботи пунктів пропускання i скорочення часу простою поїздів необхідно удосконалювати та приводити до єдиних стандартів технологію роботи пунктів пропускання, упроваджувати використання електронної інформації i документообігу в процес перевезення вантажів.

Для забезпечення ефективного використання технічних засобів станції, якісного виконання функцій 3 приймання та відправлення поїздів 3 найменшим часом перебування вагонів на станції та збереження вантажів необхідно розробити типовий технологічний процес (ТТП) роботи прикордонних передавальних станцій, в якому буде чітко визначено організацію роботи робітників станції та контролюючих організацій.

\section{Список літератури}

1. Основы технологии работы межгосударственной передаточной станции [Текст] - К.: Государственная администрация железнодорожного транспорта Украины. Укрзализныця, 1997. -28 c.

2. Альошинський, Є.С. Пропозиції щодо розробки положень типового технологічного процесу роботи прикордонних передавальних станцій України [Текст] / Є.С. Альошинський, О.С. Пестременко-Скрипка, О.В. Невзорова // Зб. наук. праць. - Харків: УкрДАЗТ, 2012. Вип. 131. - С. 18-26.

3. Акулиничев, В.М. Применение математических методов и вычислительной техники в эксплуатации железных дорог [Текст] / В.М. Акулиничев, В.А. Кудрявцев, П.А. Шульженко. - М.: Транспорт, 1973. - С. 64-66.

4. Корреляционный и регрессионный анализ в MS Excel и в статистическом комплексе SPPS [Электронный pесурс]: методические рекомендации / Профессиональноориентированные экономические информационные системы; Минский филиал МЭСИ. Режим доступа: nashaucheba.ru/v40437/?download=15.

5. Макаренко, М.В. Краткий справочник показателей эксплуатационной работы железных дорог Украины [Текст] / М.В. Макаренко. - Киев, 2001. - С. 36-39.

Ключові слова: прикордонна передавальна станція, простій вагонів, оборот вагонів, коефіцієнт кореляції, типовий технологічний процес.

\section{Анотації}

Проведено аналіз впливу простою міжнародного вагонопотоку на оборот вагонів. Для визначення ступеня взаємозв'язку між оборотом по залізниці та середньодобовим простоєм вагонів на прикордонних передавальних станціях був використаний кореляційний аналіз. Обгрунтовано необхідність розроблення типового технологічного процесу роботи прикордонних передавальних станції для забезпечення прискорення роботи пунктів пропускання і скорочення часу простою поїздів.

Проведен анализ влияния простоя международного вагонопотока на оборот вагонов. Для определения степени взаимосвязи между оборотом по дороги и среднесуточным 
простоем вагонов на пограничных передаточных станциях был использован корреляционный анализ. Обоснована необходимость разработки типового технологического процесса работы пограничных передаточных станций для обеспечения ускорения работы пунктов пропуска и сокращения времени простоя поездов.

The analysis influence of outage international car traffic volume on the turn of carriages. For determination degree of intercommunication between a turn for roads and average daily outage carriages on the frontier transmission stations a cross-correlation analysis was used. The necessity of work process technological model development the frontier transmission stations is reasonable for providing of acceleration work the points of admission and reduction the time outage of trains. 